\title{
Rasmus Rask og det italienske verbalsystem
}

\section{Viggo Bank Jensen}

\begin{abstract}
The great Danish linguist Rasmus Rask (1787-1832) published a short Italian grammar in 1827. His work is analytic and discursive. In my article I shall present and discuss Rask's exposition of the Italian verbal system. I shall focus on two elements: 1) Rask's use of a Danish terminology which has some similarities with Reichenbach's system; 2) Rask's allocation of condizionale as an indicative tense, in contrast to a long Italian grammatical tradition of having condizionale as an independent mood. I shall show that Rask's consistent use of his tense terminology throws a critical light on the Reichenbach system and further argue that the study of Rask's treatment of condizionale can give us a basis for some clarification and inspiration in the didactics of teaching the Italian language.
\end{abstract}

Nøgleord: Rask, Reichenbach, condizionale, det italienske verbalsystem

\section{Introduktion}

Rasmus Rask (1787-1832) tillægges normalt en central rolle i den tidlige udvikling af den historiske og komparative sprogvidenskab. Hans indsats inden for romansk sprogvidenskab har traditionelt haft mindre bevågenhed, om end der i de seneste 70 år er kommet fremstillinger der fokuserer på Rask som romanist, og især som hispanist. ${ }^{1}$ I hispanistikken har Rask siden 1946 fået en vis plads på grund af sit tempussystem for spansk, som ifølge Carlos Clavería (1946) "måske er det berømteste forlæg for Andrés Bellos analyse af betydningerne af de spanske tempora" (cit. efter (Kuhl-

1. Claverìa (1946), Sletsjøe (1957), Kuhlmann Madsen (1994), samt den spanske oversættelse ved Josefa Dorta af den spanske sproglære (Rask [1824] 2001). 
mann Madsen 1994); og Bellos tanker og terminologi har på dette punkt dannet baggrund for 1994-udgaven af det Spanske Akademis grammatik (Kuhlmann Madsen 1994).

Rasks italienske formlære har imidlertid ikke tidligere været underlagt en selvstændig analyse. ${ }^{2}$ Det er generelt svært at finde lingvister der direkte har udtalt sig om Rasks værk om italiensk. En af de få der har ytret sig positivt om Rasks italienske formlære, er Otto Jespersen. Et sted fremhæver han Rasks fremstilling af forholdet til latin med hensyn til de vigtigste lydlove (Jespersen 1918: 63). ${ }^{3}$ Andetsteds skriver han: "som dreng læste jeg begejstret om Rasmus Rask og satte mig ved hjælp av hans grammatikker noget ind i islandsk, italiænsk og spansk" (Jespersen 1932: 7). Over for disse positive beskrivelser står Paul Diderichsens noget mere kritiske vurdering af Rasks to romanske grammatikker. Diderichsen mener at Rask skriver sine "nysproglige grammatikker" i en periode hvor han er uden videnskabelig skarphed, og at de "bliver til som hjælpemidler for hans private sproglærervirksomhed" (Diderichsen 1960: 145).

I Rasks første publicerede værk (Rask 1811) omtaler han en plan om at udarbejde grammatikker over forskellige sprog på baggrund af samme model (dog tilpasset det enkelte sprogs særkende). Som del af dette projekt udgiver han i 1824 en spansk sproglære og i 1827 Italiensk Formlare udarbejdet efter samme Plan som den spanske Sproglere. Bogen om italiensk mangler et afsnit om "Ordföjning", det er baggrunden for at Rask vælger at kalde den "Formlære".

I denne artikel vil jeg først redegøre for Rasks forudsætninger for at skrive værket og dernæst præsentere Rasks fremstilling af det italienske verbalsystem. Der vil især blive fokuseret på to forhold: 1) Terminologien. Rask bruger danske betegnelser og i forhold til de forskellige tempusformer bruger han en terminologi der har visse lighedstræk med Reichenbachs system (1947). 2) Rasks indplacering af condizionale. I de sidste 250 års italienske grammatiktradition indplaceres condizionale typisk som selvstændig modus. Rask derimod indplacerer condizionale som indikativtempus, men kommer i praksis også til at diskutere condizionales dobbelthed. Jeg vil afrundende diskutere hvad man kan bruge Rasks beskrivelse til i dag i forhold til studiet af italiensk.

2. I en oversigt over danske italienskgrammatikker nævner Gunver Skytte (1997: 301) Rasks værk, men analyserer det ikke.

3.. Se også Bank Jensen (2016) og Basbøll \& Bank Jensen (2015: 163-64). 


\section{Rasmus Rask og hans forudsatninger for at arbejde med italiensk grammatik}

Rask bliver født i 1787 i et husmandshjem lidt uden for Odense, starter i Odense Skole (en latinskole) i 1801 og fortsætter i Odense Katedralskole. I skolen møder Rask blandt andre N.M. Petersen, der er en vigtig kilde til Rasks liv. I skolen bliver Rask undervist i latin og græsk samt tysk og fransk, men ved siden af lektionerne studerer han selvstændigt en lang række andre sprog. Han er især optaget af (old)islandsk, men allerede i skoletiden studerer han også angelsaksisk, møsogotisk, færøsk, grønlandsk og kreolsk. Rask er tilsyneladende ikke så begejstret for det franske sprog. ${ }^{4}$

Rask begynder på universitetet i 1807, og fra dette tidspunkt begynder andre romanske sprog som italiensk, portugisisk og senere spansk at optræde i Rasks noter og breve. N.M. Petersen skriver ([1834] 1870: 317): "Fra 1808 af havde Rask fattet den idé, efter én plan efterhånden at udarbejde og udgive sproglærer i de vigtigste europæiske og asiatiske sprog”. I et brev fra 19. marts 1812 fortæller Rask: "jeg har sådanne arbejder over en del af dem færdige, over en del andre begyndt. Lappisk, Svensk, Engelsk, Hollandsk, Møsogotisk, Angelsaksisk, Portugisisk har jeg omtrent færdige. Tysk, Fransk, Italiensk, Græsk, Latin har jeg begyndt og har stykker deraf færdige" (citeret efter Rönning 1887: 26). I Det Kongelige Biblioteks samling af Rasks optegnelser findes da også et par sider om italiensk der stammer fra denne periode. Disse sider handler især om høflighedsformer ved tiltale. Rask er på en syv år lang rejse (1816-23) med Asien som mål. I 1822 "på sejladsen fra Kolombo studerede han Italiensk og Fransk til tidsfordriv ... [Året efter] på tilbagerejsen til Europa sluttede han sine udkast til den franske og italienske verbaltheori, samt sit udkast til den spanske gerningsordslære", skriver N.M. Petersen ([1834] 1870: 307). I 1824 udkommer så Spansk Sproglare efter en ny Plan udarbejdet af Prof. R. Rask og i 1827 altså den italienske formlære. Et udkast til en fransk sproglære bliver udgivet af Rasks bror (Rask 1834-38 III: 347-382), mens en portugisisk sproglære synes at være gået tabt (Sletsjøe 1957: 42-43). Rasks optegnelser om italiensk fra denne periode fokuserer især på lydlige forhold, fx minimalpar (pésca/pèsca = fiskeri/fersken) hvor distinktionen lukket/åbent e har semantiske konsekvenser.

4. Sletsjøe (1957: 42) skriver om fransk "langue qu'il n'aime pas." (uden dog at angive kilden til denne vurdering). Men også i Fortalen (9-10) til Italiansk Formlare får man lidt denne opfattelse idet det fremhæves som behageligt at man på italiensk direkte kan bestemme grammatisk køn på libro og libra, til forskel fra fransk hvor Rask skriver: "hvilken Möje koster det ikke blot at lære Reglerne for Navneordenes Kön; f.E. at livre, en Bog, er af Hankönnet, men livre, et Pund af Hunkönnet." I Rask (1818: 27) foreslår han også at man lærer italiensk før fransk. 
Rasks første udgivelse er Vejledning til det Islandske eller gamle Nordiske Sprog (1811), hvor han for første gang beskriver et sprogs grammatik efter sin "plan". I Fortalen tager han afstand fra en præskriptiv grammatik til fordel for en mere deskriptiv fremstilling af sprogbrugen, og der inddrages endvidere et diakront perspektiv.

Syv år efter udkommer så Rasks hovedværk Undersögelse om det gamle Nordiske eller Islandske Sprogs Oprindelse. Et af det Kongelige Danske VidenskabersSelskab kronet Prisskrift (1818). Efter en længere teoretisk-metodisk indledning beskrives en lang række sprog i et komparativt perspektiv. Italiensk og de øvrige moderne romanske sprog behandles kun flygtigt, mest udførligt i følgende citat:
"Den romanske [Sprogklasse] er meget udbredt, dertil hører Itali- ensk, Spansk, Portugisisk og Fransk, men alle disse Sprog ere mere mærkværdige for deres Uddannelse, Velklang og Skriftrigdom, end for Alde og Oprindelighed. Det er bekjendt at de alle ere opkomne efter det rommerske Riges Fald og længe efter, da den Forvirring, som de indvandrende gotiske Folkeslag foraarsagede i det gamle latinske, begyndte at sætte sig, dog saa at det gamle Stof fik aldeles Overhaand og kun ordnede sig i en ny Form.” (Rask 1818: 159)

Efter Rasks lange rejse er der mange forventninger om at Rask vil udgive et værk om sanskrit. I stedet udkommer den spanske sproglære i 1824. De fleste samtidige omtaler af denne grammatik er derfor præget af skuffelse over at værket ikke behandler et helt andet sprog. Det har sandsynligvis haft stor betydning for at denne grammatik (og også den efterfølgende italienske formlære) er blevet "overset" i en lang periode.

Rasks sproglige spændvidde spiller en stor rolle i den italienske formlære. Rask inddrager ofte sammenligninger med andre moderne romanske sprog, med latin og græsk, og i et vist omfang med tysk og engelsk. Rask omtaler i sin Fortale til bogen en lang række grammatikker han har benyttet sig af. De to som Rask især forholder sig til, er to tysksprogede italienskgrammatikker af Valentini (1824) og af Fernow (1804). Rask nævner ingen grammatikker fra den gængse italienske grammatiktradition. Generelt er Rasks fremstilling af den italienske grammatik analyserende og diskuterende, samt som nævnt præget af kontrastive indslag. 


\section{Kort introduktion til Rasks italienske formlære og hans begrundelser for udgivelsen}

Værket har en otte siders Fortale (pagineret for sig som 5-12). ${ }^{5}$ Selve hovedteksten i bogen er på 74 sider +1 rettelsesblad. Den er inddelt i to hovedkapitler ("Bogstavlære" og "Formlære"), der igen er inddelt i afsnit og underafsnit. Værket er også inddelt i paragraffer.

Bogstavlæren med regler for udtale og overgange fra latin fylder 11 sider (§§ 1-27). Formlæren indledes med en temmelig kort behandling af navneord og tillægsord (pp. 11-18, §§ 28-49), efterfulgt af et relativt langt afsnit om stedord (pp. 18-28, §§50-77). Bortset fra de sidste to sider handler resten af bogen om "Gjerningsordene".

$\begin{array}{lll}\text { Gjerningsordene hos Rask } & \text { pp. 29-73 } & \S 78-160 \\ \text { Almindelig Oversigt } & \text { pp. 29-33 } & \S 78-85 \\ \text { Den åbne Hovedart } & \text { pp. 33-46 } & \S 86-112 \\ \text { Den lukte Hovedart } & \text { pp. 46-54 } & \S 113-130 \\ \text { Gjos. omskrevne Böjning } & \text { pp. 55-64 } & \S 131-147 \\ \text { Forskjellige Arter af Gjerningsord } & \text { pp. 64-73 } & \S 148-160\end{array}$

Som det fremgår af oversigten, fylder behandlingen af verberne ("Gjerningsordene") meget i bogen, 44 ud af 74 sider eller ca. $60 \%$. Halvdelen af Rasks afsnit om verber udgøres af opstilling og diskussion af konjugationsparadigmer (afsnit $\mathrm{B}$ og $\mathrm{C}$ ). I min artikel fokuserer jeg på de tre øvrige underafsnit om verber, altså A, D og E.

I Fortalen giver Rask først og fremmest en videnskabelig begrundelse for udgivelsen af Formlæren. "Det lille Arbejde, som her overleveres Almenheden, er et Forsøg på at fremstille den italiænske Sprogbygning efter det System, som jeg anser for det naturligste, og derfor ene rigtige i alle den japetiske ${ }^{6}$ Folkeæts Tungemål” (Rask 1827: Fortale: 1). Og han fortsætter to sider længere fremme: "Det har derfor længe været min Agt ... at levere Sproglærer over de forskjellige dannede Sprog af vor japetiske Folkeæt efter ét og samme System" (ibid: Fortale: 3). Det synes at være et (videnskabeligt) formål i sig selv at opstille et fælles system der kan lette sammenligningen mellem forskellige sprog. Men Rask giver også didaktiske begrundelser; det

5. Når jeg citerer fra Fortalen er det direkte markeret. De øvrige sidehenvisninger til værket gælder hovedteksten (der er nummereret 1-74).

6. "Japetisk" bruges af Rask nogenlunde som 'indoeuropæisk' i dag. 
"letter Arbejdet med at lære Sproget betydelig" og letter "også Arbejdet med at lære de andre beslægtede Sprog overordentlig" (ibid: Fortale: 6). Og målet er at give en "kort og let overskuelig Fremstilling af den italiænske Sprogbygning" til "de unge Studerende" (ibid: Fortale: 10). Rask forudsætter kendskab til latin hos sine læsere og påpeger at det italienske sprog "fordrer meget ringe Anstrængelse, når man forstår Latin". På den måde kan det sure latinske sprogstudium via italiensk føre til læsning af fem århundreders litteratur fra "det italiænske Bogvæsen", der har frembragt "de udødeligste Mesterværker både i bunden og ubunden Stil" (ibid: Fortale: 9). Rask lægger altså vægt på at italiensk kan bruges til lasning. Rask lægger dog også vægt på udtale idet han i Fortalen fremhæver at han har givet en udtalemarkering, nemlig om e og o er lukket eller åbent. Rask påpeger yderligere at italiensk kan skabe sammenhæng mellem skolefagene latin og fransk fordi italiensk er tættere på latin end fransk.

\section{Nyere italiensk fremstilling af paradigmet for italienske verber}

Inden jeg går over til analysen af Rasks fremstilling, vil jeg kort vise et typisk eksempel på en nyere italiensk opstilling af paradigmet for de finitte former af italienske verber i aktiv. Jeg gengiver dog kun formerne i 1. person singularis (i imperativ er gengivet 2. person singularis).

\begin{tabular}{|l|l|l|l|}
\hline \multicolumn{5}{|c|}{ INDICATIVO } \\
\hline PRESENTE & IMPERFETTO & PASSATO REMOTO & FUTURO SEMPLICE \\
\hline amo & amavo & amai & amerò \\
\hline $\begin{array}{l}\text { PASSATO } \\
\text { PROSSIMO }\end{array}$ & TRAPASSATO & TRAPASSATO & FUTURO \\
PROSSIMO & REMOTO & ANTERIORE \\
\hline ho amato & avevo amato & ebbi amato & avrò amato \\
\hline \multicolumn{5}{|c|}{ CONGIUNTIVO } \\
\hline PRESENTE & PASSATO & IMPERFETTO & TRAPASSATO \\
\hline ami & abbia amato & amassi & avessi amato \\
\hline \multicolumn{2}{|l|}{ CONDIZIONALE } & \multicolumn{2}{c|}{ IMPERATIVO } \\
\hline PRESENTE & PASSATO & PRESENTE \\
\hline amerei & avrei amato & ama (2. person singularis) \\
\hline
\end{tabular}

Figur 1: Skematisk opstilling af finitte italienske verbalformer i aktiv (1.person, singularis), baseret på Trifone \&̊ Palermo (2007: 121).

Som det fremgår af figuren, opstilles fire modi i rækkefølgen: indicativo, congiuntivo, condizionale, imperativo.

Mario Squartini vælger i sin artikel om verbets modi i Treccanis Enciclopedia dell'Italiano (2011) at opstille dem i en anden rækkefølge, nemlig: 
indicativo - condizionale - congiuntivo - imperativo. Condizionale er altså her placeret tættere på indicativo end congiuntivo. I artiklen fremhæver Squartini især syntaktiske fællestræk for indicativo og condizionale, samt syntaktiske og pragmatiske forskelle mellem condizionale og congiuntivo.

\section{Rasks fremstilling af det italienske verbalsystem}

De semantiske relationer mellem verbalformerne præsenteres først og fremmest i $\S$ 78-79 og 131-147. Rask behandler i $\S$ 78-79 de usammensatte former, først fra $§ 131 \mathrm{og}$ fremefter de sammensatte ("omskrevne" hos Rask) former. Bortset fra diatese introduceres verbets grammatiske hovedkategorier af Rask i § 78 i denne rækkefølge: modus ("Måde"), tempus ("Tid"), aspekt (har ikke nogen betegnelse hos Rask, men introduceres via henvisning til græsk aorist og latinsk perfectum) og endelig forskellen mellem finitte former og infinitte former ("Afledsformer"). Diatese introduceres først i § 139. Rasks interlingvistiske blik for aspektforhold kommer til udtryk i følgende passus:

"Fortid er den fortællende Tid, og svarer således til den græske aorist, men kun halv til den latinske perfectum, der foruden den fortællende Fortids Betydning, tillige har en anden, som kunde kaldes Förnutidens, hvilken Italiænerne ligesom Franskmændene og vi udtrykke ved Omskrivning med har." (Rask 1827: 29)

'Fortællende' hos Rask skal ikke forstås i Harald Weinrichsk forstand (som modsætning til 'kommenterende'), men som modsætning til 'beskrivende'. Andetsteds skriver Rask (ibid: 60) også mere uddybende om aspektforhold, når han konkret om forskellene i anvendelsen af "Datid" og "Fortid" skriver følgende: "Datiden beskriver noget varende eller oftere gjentaget og sædvanligt, Fortiden fortæller noget overgående, som én Gang for alle er skjet, omtrent som det latinske preteritum imperfectum og perfectum."

Ifølge Rask (ibid: 29) har "det egentlige Gjerningsord", dvs. det finitte verbum, "tre Måder: den fremsettende, betingende og bydende." Det er interessant at betegnelsen for konjunktiv tager udgangspunkt i rollen som protasis i hypotetiske konstruktioner. Det spiller en vigtig rolle i Rasks diskussion af condizionale. 


\begin{tabular}{|l|l|l|l|}
\hline & $\begin{array}{l}\text { Rasks termer }+ \\
\text { italiensk terminologi }\end{array}$ & $\begin{array}{l}\text { Rasks termer + } \\
\text { italiensk terminologi }\end{array}$ \\
\hline $\begin{array}{l}\text { parlo } \\
\text { (jeg taler) }\end{array}$ & $\begin{array}{l}\text { Nutid } \\
\text { Presente }\end{array}$ & $\begin{array}{l}\text { ho parlato } \\
\text { (jeg har talt) }\end{array}$ & $\begin{array}{l}\text { Förnutid } \\
\text { Passato prossimo }\end{array}$ \\
\hline $\begin{array}{l}\text { parlavo } \\
\text { (jeg talte) }\end{array}$ & $\begin{array}{l}\text { Datid } \\
\text { Imperfetto }\end{array}$ & $\begin{array}{l}\text { avevo parlato } \\
\text { (jeg havde talt) }\end{array}$ & $\begin{array}{l}\text { Fördatid } \\
\text { Trapassato prossimo }\end{array}$ \\
\hline $\begin{array}{l}\text { parlerò } \\
\text { (jeg vil tale) }\end{array}$ & $\begin{array}{l}\text { Fremtid/Efternutid } \\
\text { Futuro (semplice) }\end{array}$ & $\begin{array}{l}\text { avrò parlato } \\
\text { (jeg vil have talt) }\end{array}$ & $\begin{array}{l}\text { Förfremtid } \\
\text { Futuro anteriore }\end{array}$ \\
\hline $\begin{array}{l}\text { parlerei } \\
\text { (jeg ville tale) }\end{array}$ & $\begin{array}{l}\text { Eftertid/Efterdatid } \\
\text { Condizionale presente }\end{array}$ & $\begin{array}{l}\text { avrei parlato } \\
\text { (jeg ville have talt) } \\
\text { [jeg ville tale] }\end{array}$ & $\begin{array}{l}\text { Föreftertid } \\
\text { Condizionale passato }\end{array}$ \\
\hline $\begin{array}{l}\text { parlai } \\
\text { (jeg talte) }\end{array}$ & $\begin{array}{l}\text { Fortid } \\
\text { Passato remoto parlato } \\
\text { (jeg havde talt) }\end{array}$ & $\begin{array}{l}\text { Förfortid } \\
\text { Trapassato remoto }\end{array}$ \\
\hline
\end{tabular}

Figur 2: Rasks indikativtempora (med fed skrift) $i$ den rakkefolge han selv presenterer dem.

Figuren er en skematisk fremstilling af de 10 tempora som Rask oplister under overskriften "Fremsættende Måde" (altså indikativ), jf. Rask (ibid: 30, 56). Rasks opstilling af det italienske verbalsystem er præget af tre særlige forhold: 1) han benytter danske termer, delvist udviklet af ham selv, ${ }^{7}$ 2) han indplacerer i skemaet condizionale-formerne som (indikative) tempusformer, 3) hans opstilling tager udgangspunkt i morfologien, så han behandler de syntetiske former for sig først, og først senere de analytiske, jf. min opstilling i skemaet. Under Rasks betegnelser har jeg angivet de mest gængse betegnelser i italienske grammatikker, jf. figur 1. Rask oversætter ikke selv eksemplerne i paradigmeopstillingerne til dansk; oversættelserne af verbalformerne er mine, og de skal tages med et vist gran salt.

Det er karakteristisk for hele Rasks analyse af tempus at han ikke færdigbehandler én verbalform ad gangen, men hele tiden relaterer til andre former af verbet. Således skriver han fx at "Fremtid" og "Eftertid" egentlig mere præcist burde kaldes "Efternutid" og "Efterdatid" da de forholder sig på samme måde til hinanden som "Nutid" og "Datid", han holder dog fast i at kalde dem "Fremtid" og "Eftertid". Efter at have indplaceret fire af fem "Tider" i forhold til hinanden behandler han "Fortid", altså det der normalt kaldes 'passato remoto'. Som det fremgår af citaterne i starten af afsnittet, har Rask overordnet set en udmærket forståelse af forskellen i brug mellem "Datid" og "Fortid", og hans eksempler er også oversat og analyseret udmærket. Han bemærker tillige korrekt at distinktionen mel-

7. Diderichsen (1960: 92ff.) gør en del ud at understrege at Rask slet ikke, som det ellers fremgår af mange ODS-opslag, skal have æren for at være ophavsmand til den danske grammatikterminologi. Ifølge Diderichsen overtager Rask som regel nogle betegnelser fra tidligere grammatikere. I ODS får Rask også æren for termen "Eftertid", der er central i denne artikel, og her er Rasks førsteret uantastet af Diderichsen, der ikke nævner termen i sin ellers fyldige gennemgang. 
lem de to former er svær at fange for danskere. Ikke desto mindre er hans danske betegnelser problematiske da de ikke er ikke særlig informationsgivende om forskellen i anvendelse af de to former. Hvis Rask vil benytte en ren tids- eller rækkefølge-terminologi, mangler han i sin betegnelse for 'imperfetto' et element der indebærer samtidighed, til forskel fra Andrés Bello (jf. Kuhlmann Madsen 1994: 197, 211).

Rask argumenterer for at alle de omskrevne tider skal benævnes "efter den Tid, hvori Hjælpeordet sættes, blot med foransat för, fordi den tilföjede Tillægsform er forbigangen, og medfører det Begreb, at Gjerningen er skjet förend den Tid, Hjælpeordet tilkjendegiver" (ibid: 55).

Ifølge Rask er forskellen mellem de omskrevne og de simple tidsformer om tiden er løbende eller udløben. "Det kommer nemlig ikke an på Gjerningens fuldkomne Tilendebringelse, ej heller på Tidsrummets Længde, men blot om det er udrundet eller indeværende" (ibid: 59). Han analyserer eksemplet Il D. di G. arrivò jeri l'altro e oggi mi ha favorito di venire a vedermi, ${ }^{8}$ som han selv oversætter: "Hr. D. af G. ankom i forgårs, og har idag været så artig, at komme og se til mig". Rask analyserer eksemplet på den måde at arrivò står i simpel Fortid fordi tidsrummet "i forgårs" er udløbet, mens ha favorito står i Førnutid fordi "idag”" er løbende tid; og påpeger at det svarer til dansk sprogbrug, jf. hans oversættelse. Det er væsentligt at Rasks eksempler indeholder tidsadverbialer som analysen af verbalformerne kan knyttes til. Feri l'altro i den første sætning angiver klart en "udløben tid" (og derfor brug af "Fortid"), mens oggi i den anden sætning angiver at denne er "løbende tid" og derfor ud fra Rasks præmisser skal have "Førnutid".

Rasks analyse er ikke så forskellig fra hvad en moderne analyse kunne finde på at sige. Jeg vil dog nævne at Rasks analyse kun passer på klassisk italiensk litteratursprog, men ikke forholder sig til den udbredte standard i norditaliensk hvor passato remotos funktioner er overtaget af passato prossimo, der således her har to funktioner, lidt jævnfør den latinske perfectum, som Rask selv refererer til i citatet ovenfor. Det anførte eksempel peger også på at Rask ikke er bleg for af og til at bruge ældre eksempler.

Med hensyn til condizionaleformerne forudsætter Rask at man kan benytte den simple nutidsform ("Eftertid" hos Rask) til at angive fortids fremtid. Fortids fremtid-anvendelsen er på italiensk i dag kun knyttet til den sammensatte form, på Rasks tid var den stadig i vidt omfang, i al fald

8. Eksemplet stammer oprindeligt fra Guido Bentivoglio (1579-1644), Rask har det nok fra Valentini (1824: 310-11). 
i litteratursproget, knyttet til den usammensatte form. ${ }^{9}$ Det er i det sidste Rask tager udgangspunkt i sin teoretiske analyse, han halter altså lidt bagud i forhold til sprogudviklingen, hvilket også viser sig i hans eksempelanvendelse.

\section{En sammenligning af Rasks fremstilling med andre tempora-inddelinger}

I det følgende vil jeg sætte Rasks fremstilling i forhold til Steen Vikners omtale af forskellige 8-tempora- og 9-tempora-inddelinger - med Reichenbach som primært eksempel på sidstnævnte (Vikner 2003).

Som omtalt ovenfor skriver Rask: "Fremtid og Eftertid forholde sig til hinanden ligesom Nutid og Datid og skulde kunne kaldes Efternutid, Efterdatid;" (Rask 1827: 29). Med udgangspunkt i dette citat og den øvrige fremstilling kunne man skematisk fremstille Rasks tempora på følgende måde:

\begin{tabular}{|c|c|c|c|c|}
\hline $\begin{array}{l}\text { Indikativ- } \\
\text { systemet }\end{array}$ & Førtidigt & $\underline{\text { Samtidigt }}$ & $\underline{\text { Før-eftertidigt }}$ & Eftertidigt \\
\hline Nutidsakse & $\begin{array}{l}\text { Førnutid } \\
\text { Passato } \\
\text { prossimo }\end{array}$ & $\begin{array}{l}\text { Nutid } \\
\text { Presente }\end{array}$ & $\begin{array}{l}\text { Førfremtid } \\
\text { Futuro anteriore }\end{array}$ & $\begin{array}{l}\text { Fremtid(=Efternutid) } \\
\text { Futuro }\end{array}$ \\
\hline Fortidsakse & $\begin{array}{l}\text { Førdatid } \\
\text { Trapassato } \\
\text { prossimo } \\
\text { Førfortid } \\
\text { Trapassato } \\
\text { remoto }\end{array}$ & $\begin{array}{l}\text { Datid } \\
\text { Imperfetto } \\
\text { Fortid } \\
\text { Passato remoto }\end{array}$ & $\begin{array}{l}\text { Før-Efter(da)tid } \\
\text { Condizionale } \\
\text { passato/composto }\end{array}$ & $\begin{array}{l}\text { Efter(da)tid } \\
\text { Condizionale } \\
\text { presente/semplice }\end{array}$ \\
\hline
\end{tabular}

Figur 3: Rasks fremstilling i skema baseret på to tidsakser

"Datids"- og "Fortids"-formerne er indplaceret i samme rubrik da Rask behandler dem parallelt i forhold til fortidsaksen. Mens Rasks inddeling således nogenlunde synes at svare til de 8-tempora-inddelinger som Vikner henviser til, ${ }^{10}$ så er der ikke så markante ligheder mellem Rasks tempusterminologi og terminologien i de seks 8-tempora-fremstillinger. Især er

9. Det er relevant i denne sammenhæng at Rasks italienske grammatik udkommer nogenlunde samtidig med I promessi sposi af Alessandro Manzoni, der bruger begge condizionaleformer til at angive fortids fremtid. Brambilla Ageno (1964: 350) påpeger at Manzoni mest typisk bruger condizionale semplice til at angive fortids fremtid.

10. Det drejer sig om Mikkelsen (1911), Jørgensen (1964), Weinrich (1964), Vikner (1985), Thieroff (1992: 59), Kamp \& Reyle (1993: 601). 
det påfaldende at ingen af dem har et generelt "Efter"/posterior-begreb, men bruger forskellige versioner af "futurum" hvilket har en lidt mere afgrænset betydningszone. ${ }^{11}$

Rasks tempus-terminologi minder derimod på vigtige punkter om Reichenbachs, og jeg har derfor fundet det interessant at undersøge om Rasks analyse kan bruges til at problematisere Reichenbachs analyse. Det er vigtigt at understrege at terminologien er et vigtigt punkt hos Reichenbach; han bringer således (1947: 297) et skema med to kolonner: New Name over for Traditional Name. Generelt erstatter han "perfect" med anterior (svarende til Rasks "før"), derudover indfører han begrebet posterior (svarende til Rasks "Efter").

I figur 4 bringer jeg et skema der viser fællestræk mellem Rasks og Reichenbachs terminologi. Rask kalder den sammensatte condizionale for "Förefter(da)tid". Hvis man tager Rasks betegnelse "Førefter(da)tiden" på ordet, findes der ikke en plads til den i figur 4. Problemet ville selvfølgelig kunne "løses" ved i stedet for "Eftertid" at bruge den sammensatte condizionaleform som nu i praksis er den gængse. Under alle omstændigheder afslører Rasks logik et punkt som Reichenbach ikke behandler, nemlig at man kan udtrykke en 'førfremtid i fortiden', ${ }^{12}$ på italiensk altså en futuro anteriore transponeret til fortiden. ${ }^{13}$ Normalt udtrykkes dette med en form "lånt" fra konjunktiv, som fx: Marco mi ha detto che sarebbe andato al cinema quando avesse finito $i$ compiti (Marco fortalte mig at han ville gå i biografen når han var færdig med sine lektier), men Rasks "Förefter(da)tid" kan faktisk også optræde i denne position som det fremgår af følgende eksempel nedenfor: Sapevo che quando si sarebbero messi a cantare, qualcuno del tavolo aurebbe gridato ... (Jeg vidste, at når de gav sig til at synge, ville nogen ved bordet skrige ... .). ${ }^{14}$

11. Hos Vikner selv kan man dog se en terminologisk ændring fra 1985 til 2003, nemlig med hensyn til betegnelserne for de tre træk hans 8-deling bygger på: I Vikner (1985: 94) er det [+/-Past], [+/-Future] og [+/-Perfect], i 2003 er [+/-Future] blevet byttet ud med [+/-Posterior]. Denne ændring indebærer dog ikke at "post" indgår i hans tempusbetegnelser.

12. 'maskeret futurum exactum' (Hyllested \& Østergaard 1966: 167), 'futurum pluskvamperfektum' (Vikner 2003: 92 ff.).

13. Vikner (1985: 82, 2003: 92) peger på det samme problem hos Reichenbach. Matzen (1893: 279 ff.) som er et af Vikners andre eksempler på 9-tempora-inddeling (og som i øvrigt bruger en terminologi der ligger meget tæt på Rasks), demonstrerer i praksis at han er opmærksom på dette problem ved i to noter til 9-punkts-skemaet at supplere med en "Før-Efterfortid" og tilmed bringe to eksempler.

14. Eksemplet er fra Bach \& Schmitt Jensen (1990: 547). 
Her kan avrebbe gridato opfattes som fortids fremtid ("Eftertid") og sarebbero messi som fortids førfremtid ("Føreftertid"). I forhold til Rasks benævnelser er der dog mindst to problemer: der hvor der ifølge Rask skulle være "Eftertid", er der også "Føreftertid", og eksemplet afspejler en undtagelse i verbalsystemet.

\begin{tabular}{|c|c|c|c|}
\hline Indikativ-systemet & Førtidigt & $\underline{\text { Samtidigt }}$ & Eftertidigt \\
\hline Fremtidsakse & $\begin{array}{l}\text { Førfremtid } \\
\text { Futuro anteriore } \\
\text { Anterior future }\end{array}$ & $\begin{array}{l}\text { Fremtid } \\
\text { Futuro } \\
\text { Simple future }\end{array}$ & $\begin{array}{l}\text {--- } \\
\text { Ikke som fleksiv } \\
\text { Posterior future }\end{array}$ \\
\hline Nutidsakse & $\begin{array}{l}\text { Førnutid } \\
\text { Passato prossimo } \\
\text { Anterior present }\end{array}$ & $\begin{array}{l}\text { Nutid } \\
\text { Presente } \\
\text { Simple present }\end{array}$ & $\begin{array}{l}\text { Fremtid(=Efternutid) } \\
\text { Futuro semplice } \\
\text { Posterior present }\end{array}$ \\
\hline$\underline{\text { Fortidsakse }}$ & $\begin{array}{l}\text { Førdatid } \\
\text { Trapassato prossimo } \\
\text { Førfortid } \\
\text { Trapassato remoto } \\
\text { Anterior past }\end{array}$ & $\begin{array}{l}\text { Datid } \\
\text { Imperfetto } \\
\text { Fortid } \\
\text { Passato remoto } \\
\text { Simple past }\end{array}$ & 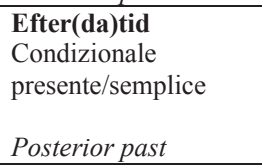 \\
\hline
\end{tabular}

Figur 4: Et "Reichenbach-skema" baseret på Rasks fremstilling.

Figur 4 fremstiller det italienske tempus-system i indikativ i Rask-udgave som det kunne fremstilles ud fra et Reichenbach-inspireret skema. Rasks betegnelser er angivet med fede typer, Reichenbachs med kursiverede. Som nævnt i forbindelse med figur 3 er princippet i figur 4 ikke den mest oplagte måde at skematisere Rasks fremstilling, men jeg tillader mig at gøre det alligevel, da det fremhæver terminologi-overensstemmelserne.

Nogle kommentarer til figur 4: 1) Rask prøver ligesom Reichenbach med en rent temporal terminologi vedrørende skemaets former; den traditionelle terminologi (jf. figur 1) inddrager typisk både tempus, aspekt og modus. 2) Det italienske sprog tvinger Rask til dobbeltformer på fortidsaksen. 3) Den i denne artikels sammenhæng mest interessante terminologi-overensstemmelse mellem Rask og Reichenbach er brugen af "Efter" / posterior, som behandles uddybende i artiklens afsnit 7. 4) Der er tre vigtige forskelle mellem de to fremstillinger: a) Rask har ingen eftertidighedskolonne på fremtidsaksen; b) i skemaet er der ingen plads til Rasks forståelse af sammensat condizionale som en (Førefter(da)tid); c) mens Reichenbach opfatter simple future og posterior present som to forskellige tempora (der på engelsk tilfældigvis har samme form), så skriver Rask direkte at "Fremtid" burde kaldes "Efternutid", Rask må vel derfor siges at opfatte det som et og samme tempus (hvilket i parentes bemærket også problematiserer mit forsøg på her i figur 4 at give en fælles skematisk fremstilling hvor det er placeret begge steder). 
Som det er fremgået af dette afsnit, kan en læsning af Rasks knap 200 år gamle analyse give anledning til at sætte spørgsmålstegn såvel ved terminologien i 8-tempora-inddelingerne som ved nogle af principperne i Reichenbachs 9-inddeling.

\section{Futuro og condizionale ("Fremtid" og "Eftertid") hos Rask}

Et af de interessante punkter i Rasks analyse er hans påpegning af en parallel semantik for futuro og condizionale via forstavelsen "Efter-", altså "Efternutid" og "Efterdatid". I dette afsnit vil jeg nøjere udrede Rasks behandling af disse former.

Rask har enkle og passende eksempler på anvendelse af "Fremtid" og "Förfremtid": vedremo che effetto ne seguirà, oversat med "vi ville se, hvad Virkningen deraf vil blive", tre giorni ancora, e Odoardo sarà partito, oversat med "tre Dage endnu og Odoardo vil være rejst" (Rask 1827: 62). Derimod er der hos Rask ingen eksempler på en "ren" fortids fremtid, alle hans eksempler indeholder noget modalt. Som eksempel på "Eftertid" giver Rask eksemplet chi l'aurebbe mai detto? (med oversættelse og kommentar af Rask: "hvem skulde nogensinde have sagt det? (nemlig för, da man endnu ikke havde set det)" (ibid: 62). I Rasks annotationer (Rask 1827ann: 62) retter han senere (korrekt) sig selv og skriver at aurebbe detto er Föreftertid. Han mangler dog stadig et condizionale-eksempel uden modalitet.

Længere fremme i teksten forklarer Rask at "Eftertid" også bruges i betingede sætninger, der afhænger af betingende. Han bringer eksemplet che sarebbe di me, s'io non potessi vederla piu!, med oversættelsen "hvad vilde der blive af mig, dersom jeg ikke kunde se hende mere!", og skriver så: "Man kunde kalde dette en betinget Fremtid, når man blot ikke forblande det med betingende Måde" (ibid: 63). Man ser altså hvordan hans terminologiovervejelser både bliver knyttet til sætningsanalysen og til didaktiske overvejelser. Han er, som det ses, lidt på vagt over for betegnelsen "betinget Fremtid" fordi den kan forveksles med "betingende Måde" (= konjunktiv).

Den sidste præcisering er vigtig. I den italienske formlære bringer Rask ikke direkte begrundelser for indplaceringen af condizionale under indikativ. Det gør han derimod i den spanske grammatik (Rask 1824). Her påpeger han i Fortalen at hans inddeling af "Tiderne og Måderne" er anderledes end hos den franske grammatiker Charlumeau de Verneuil, og i en polemik mod franskmanden argumenterer Rask for en klar distinktion mellem condizionale og konjunktiv, en distinktion der absolut ikke var indlysende 
i Rasks samtid. Den ellers meget vidende og grundige tyske grammatiker Fernow (1804) kalder fx de to condizionaleformer for 'Futuro condizionale, congiuntivo' og 'Futuro perfetto condizionale, congiuntivo'. ${ }^{15}$

Rask understreger hvordan det er vigtigt at skelne den betingende sætning, der indeholder betingelsen, fra den fremsættende, der skal stå i indikativ selv om den ofte er betinget. På baggrund af en analyse af to eksempler konkluderer Rask at "Eftertid" / "den betingede Fremtid" hører til "fremsættende Måde". Rasks analyse er ikke helt præcis, men kernen synes at være at condizionale-formerne syntaktisk optræder som verbal i hovedsætninger ligesom indikativformerne, mens konjunktiv optræder som verbal i underordnede ledsætninger (Rask 1824: 170). På den måde svarer Rasks argumentation meget til Squartinis 'syntaktiske parallelisering' mellem indikativ og condizionale (jf. afsnit 4), og Rask understreger således at condizionaleformerne ligger tættere på indikativformerne end konjunktivformerne gør, i overensstemmelse med Squartinis rækkefølge i oplistningen af modi, men i modstrid med de gængse paradigmatiske opstillinger: indikativ, konjunktiv, condizionale, imperativ (jf. figur 1).

Rasks indplacering af condizionale under indikativ er ikke uden problemer. Men hans stræben efter konsekvens og hans diskuterende tilgang får sat fokus på centrale problemstillinger. Hans skema og terminologi fanger bedre end mange andre fremstillinger condizonaleformernes dobbelthed. Med termerne "Eftertid" og "betinget Fremtid" indplacerer han relevant condizionaleformerne syntaktisk og semantisk i forhold til andre modi. Med forstavelsen "Efter-" har han desuden en term der inkluderer såvel den temporale betydning (fortids fremtid) som den logiske betydning, dvs. betinget, altså logisk efter betingelsen.

\section{Konklusion}

Det er svært at påvise direkte indflydelse fra Rasks italienske formlære i senere grammatikskrivning. I danske italienskgrammatikker findes ingen eksplicitte henvisninger til Rasks værk, generelt bruges der italienske og latinske fagtermer, eventuelt suppleret med danske termer i parentes. Rask har overordnet haft en betydning for udbredelsen af danske termer, men intet peger på at det skyldes den italienske formlære. Termen "Eftertid" optræder ikke i nogen af de danske italienskgrammatikker. I den mest

15. For uddybende sammenligning af Rasks fremstillinger med samtidige grammatikere se Bank Jensen 2013. 
omfattende danske italienskgrammatik (Bach \& Schmitt Jensen 1990: 455) begår forfatterne tilmed en "stor fejl" set med Rasks øjne, når de skriver "et udsagn i condizionale er ikke en påstand som man uden videre står inde for, det er betinget af noget andet som det forudsetter: betegnelsen condizionale (= betingende form) er derfor ganske dækkende." Rask havde jo givetvis skrevet betinget form.

Eksemplet viser at Rasks værk kan give anledning til præciseringer og didaktiske overvejelser i forbindelse med italienskundervisning.

Rask får sat fokus på:

- condizionales dobbelthed som tempus og modus;

- at de to sider har noget til fælles, via forstavelsen "efter" der kan gælde både temporalt og logisk;

- at condizionale og futuro har noget til fælles, det eftertidige;

- at condizionale ud fra et funktionelt synspunkt bør placeres mellem indikativ og konjunktiv;

- at den italienske term condizionale er meget tvetydig, fordi den både betyder betinget og betingende og bruges både om betingede verbalformer og om betingende ledsætninger.

\section{Henvisninger}

Bach, S. \& Schmitt Jensen, J. (1990). Større italiensk grammatik. København: Munksgaard.

Bank Jensen, V. (2013). Rasmus Rask \& Condizionale. En analyse af Italicnsk Formlere (1827) med fokus på Rasks verbalteori, Københavns Universitet, www.kb.dk.

Bank Jensen, V. (2016). Rask e il vocalismo tonico nelle lingue romanze.

I: Actes du XXVIIe Congrès international de linguistique et de philologie romanes (Nancy, 15-20 juillet 2013), 2 volumes. Buchi, É, Chauveau, J.P. \& Pierrel, J.M. (red.). Strasbourg: Societé de linguistique romane, 1515-1526. Ses også på http://www.atilf.fr/cilpr2013/actes/section-15/CILPR-201315-Jensen.pdf (03.01.2017)

Basbøll, H. \& Bank Jensen, V. (2015). A linguistic giant between the 18th and 20th century. Historiographia Linguistica, Vol. 42, No. 1, 153-167.

Brambilla Ageno, Franca (1964). Il verbo nell'italiano antico. Milano/Napoli: Riccardo Ricciardi Editore.

Clavería, C. (1946). La »Gramàtica española« de Rasmus Rask. Revista de filología española, XXX, 1-22. 
Diderichsen, P. (1960). Rasmus Rask og den grammatiske tradition. København: Munksgaard.

Fernow, K.L. (1804). Italienische Sprachlehre für Deutsche. Tübingen: J.G. Cottaschen Verlag.

Hyllested, P. \& Ostergaard, U. (1966). Latinsk grammatik. København: Gyldendal.

Jespersen, O. (1918). Rasmus Rask. Kjøbenhavn: Gyldendal.

Jespersen, O. (1932). Tanker og studier. København: Gyldendalske Boghandel/Nordisk Forlag.

Jørgensen, P. (1964). Tysk Grammatik III. København: G.E.C. Gad.

Kamp, H \& Reyle, U. (1993). From Discourse to Logic. Dordrecht: Kluwer.

Kuhlmann Madsen, J. (1994). Rask, Bello og Det spanske Akademis nye grammatik. I: Vindue mod den romanske verden. Skytte, G. et. al. (red.). København: Museum Tusculanum, 193-215.

Matzen, M. (1893). Modersmaalets Sproglere, udforligt og almenfatteligt fremstillet. København: Gyldendal.

Mikkelsen, K. (1911). Dansk Ordföjningslere. København: Lehmann \& Stage.

ODS = Ordbog over det danske Sprog (1918-1956). København: Det Danske Sprog- og Litteraturselskab \& Gyldendal.

Petersen, N.M. ([1834] 1870). Bidrag til Rasmus Kristian Rasks levned. I: Samlede Afhandlinger I. København: Samfundet til den danske litteraturs fremme, 217-344.

Rask, R. (1806-1810, 1820-1832). Optegnelser til Italiensk ved R. Rask. Ny kgl. saml. $4^{\circ} 149 \mathrm{c}$.

Rask, R. (1811). Vejledning til det Islandske eller gamle Nordiske Sprog. København: Schubothes Forlag.

Rask, R. (1818). Undersögelse om det gamle Nordiske eller Islandske Sprogs Oprindelse. Et af det Kongelige Danske Videnskabers-Selskab kronet Prisskrift. Kjöbenhavn: Gyldendal.

Rask, R. (1824). Spansk Sproglere efter en ny Plan udarbejdet af Prof. R. Rask. København: Beekens Forlag.

Rask, R. ([1824] 2001). Gramática Española según un nuevo Plan (ed. Dorta, J.). Madrid: Arco/Libros.

Rask, R. (1827). Italiensk Formlere udarbejdet efter samme Plan som den spanske Sproglere. København: Schultz.

Rask, R. (1827ann.). Italiensk Formlere udarbejdet efter samme Plan som den spanske Sproglere. København: Schultz. Annoteret eksemplar. Ny kgl. saml. $4^{\circ} 149 \mathrm{~d}$. 
Rask, R. (1834-38). Samlede Afhandlinger I-III (red. H.K. Rask). København: Poppske Bogtrykkeri.

Reichenbach, H. (1947). Elements of Symbolic Logic. New York: The Macmillan Company.

Rönning, F. (1887). Rasmus Kristian Rask. Et mindeskrift. København: Schønbergs Forlag.

Skytte, G. (1997). L'immagine dell'italiano attraverso gli esempi della grammaticografia danese. I: Italiano: lingua di cultura europea: atti del Simposio internazionale in memoria di Gianfranco Folena, Weimar, 11-13 aprile 1996. Stammerjohann, H. (red.). Tübingen: Narr, 299-305.

Sletsjøe, L. (1957). Rasmus Rask romaniste. Studia Neophilologica XXIX, nr. 1, 39-53.

Squartini, M. (2011). Modi del verbo. I: Enciclopedia dell'Italiano. Roma: Treccani. http://www.treccani.it/enciclopedia/modi-del-verbo_(Enciclopedia_ dell'Italiano)/ (03.01.2017).

Thieroff, R. (1992). Das finite Verb im Deutschen. Tübingen: Gunter Narr.

Trifone, P. \& Palermo, M. (2007). Grammatica italiana di base. Milano: Zanichelli.

Valentini, F. (1824). Neue theoretisch-praktische Italienische Grammatik fir Teutsche. Berlin: Amelang.

Vikner, S. (1985). Reichenbach Revisited: One, Two, or Three Temporal Relations? I: Acta Linguistica Hafniensia, 19/2, 81-95.

Vikner, S. (2003). Tempus som tre uafhængige træk. Tidsskrift for Sprogforskning, 1.1, 89-104.

Weinrich, H. (1964). Tempus. Besprochene und erzählte Welt. Stuttgart: Kohlhammer. 